\title{
Phyto-Chemical Screening and Ethno-Botanical Properties of Selected Plants of the Obafemi Awolowo University, Ile-Ife, Nigeria
}

\author{
Adejuwon $\mathrm{AO}^{* 1}$ and Tsygankova $\mathrm{VA}^{2}$ \\ ${ }^{1}$ School of Health Information Management, University College Hospital, Ibadan, Nigeria \\ ${ }^{2}$ Department for Chemistry of Bioactive Nitrogen Containing Heterocyclic Compounds, Institute of Bioorganic Chemistry and Petrochemistry of the \\ National Academy of Sciences of Ukraine, Ukraine
}

Submission: April 01,2019; Published: April 23, 2019

*Corresponding author: Adekunle Odunayo Adejuwon, School of Health Information Management, University College Hospital, Ibadan, Nigeria

\begin{abstract}
Aim: Reported cases of arthritis and typhoid fever have been on the increase in Nigeria, West Africa. This has led us into the ethno-botanical and phyto-chemical studies of some plants used in the treatment of these diseases in Nigerian traditional practice.

Materials and Methods: Twenty plants were screened for the phytochemical compounds tannins, saponins, alkaloids, flavonoids and carotenoids using standard biochemical methods. The habits of the test plants were $90 \%$ trees, $50 \%$ herbs, $40 \%$ shrubs and $20 \%$ climbers. The plant parts used were $100 \%$ leaves.

Results: All the tested plants contained high levels of varied concentrations of saponins, alkaloids and flavonoids compared to their levels of tannins and carotenoids.

Conclusion: Further studies on these secondary metabolites should shed more light into the Nigerian trado-medical claim of these plant parts. This study will be of significance and value in therapeutics and drug development.
\end{abstract}

Keywords: Plants; Phyto-chemicals; Ethnomedicines; Typhoid fever; Arthritis

\section{Introdution}

Plants have been indispensable sources of both preventive and curative medical preparations in centuries [1,2]. According to the World Health Organization (WHO), estimates of up $80 \%$ of the world's population, mostly in the developing countries have adapted trado-medicinal curative practices in health needs [3]. With a value in therapeutics, plant part preparations are used in China, France and Germany as herbal remedies with less stringent side effects as assumed in the medical world [2]. Plants have been recorded as containing phtochemicals which act as antioxidants, interfere with hormonal actions, stimulate body enzymes, interfere with DNA replication, inhibit bacterial function (bacteriocidal or bacteriostatic) [4]. In the present investigation, certain plants in Nigeria, West Africa used in trado-medical treatment of typhoid fever and arthritis were screened for phyto-chemical properties with a view to justifying their application in Nigerian traditional curatives and the possibility of the development of drugs of herbal sources for human health.

\section{Materials and Methods}

\section{Collection of plants}

Plants used in traditional practice for the treatment of arthri tis and typhoid fever: Morinda lucida, Cymbopogon citratues, Citrus aurantifolia, Citrus paradisi, Blighia Sapida were obtained along the Polytechnic Road, University of Ibadan, Ibadan, Nigeria. Spondias mombin, Azadirachta indica, Khaya grandfoliola, Momordica charantia and Alstonia boonei were gotten from the Department of Forest Resource Management, University of Ibadan, Nigeria. Musa paradisiaca, Phyllantus amarus, Carica papaya, Psidium guajava, Solenostemon monostachyus, Terminalia catappa, Ocimum gratissimum, Boerhavia diffusa, Parquetina nigrescens were collected within the premises of Mozambique Hall, Obafemi Awolowo University, Ile-Ife, Nigeria.

\section{Plant identification}

All plant samples were identified at the species level by Professor Bukola Adedeji at the Department of Botany, Obafemi Awolowo University, Ile-Ife, Nigeria.

\section{Preparation of plant materials}

The plant parts were washed thoroughly, cut into small parts and air-dried. They were then milled into coarse powder. The powdered samples were stored in glass containers at room temperature $\left(28^{\circ} \mathrm{C}\right)$. 


\section{Phyto chemical screening}

The qualitative and quantitative screening of powdered plant samples were carried out at Kappa Biotechnology Laboratories Results

Table 1: Profile of plants used for the treatment of arthritis.

\begin{tabular}{|c|c|c|c|c|}
\hline Botanical Name & Common Name & Family Name & Part Used & Habit \\
\hline Alstonia boonei De Wild & Stool wood & Apocynaceae & Leaf & Tree \\
\hline Phyllanthus amarus Schum. \& Thonn. & Stone plant & Euphorbiaceae & Leaf & Herb \\
\hline Solenostemon monostchyus (Palisot de Beauvois) Briquet & Monkey's Potato & Lamiaceae & Leaf & Herb \\
\hline Boerhavia diffusa Linn. & Pig weed & Nictaginaceae & Leaf & Herb \\
\hline Parquetina nigrescens (Afzel.) Bullock & & Asclepiadaceae & Leaf & Climber \\
\hline Carica papaya Linn. & Pawpaw & Caricaceae & Leaf & Shrub \\
\hline Spondias mombin Linn. & Hog plum & Anacardiaceae & Leaf & Shrub \\
\hline Morinda lucida (Benth.) & Brimstone tree & Rubiaceae & Leaf & Tree \\
\hline Khaya grandifoliola (Welw) CDC & Mahogany & Maliaceae & Leaf & Tree \\
\hline Blighia sapida (koenig) & Akee & Sapindaceae & Leaf & Tree \\
\hline
\end{tabular}

Table 2: Profile of plants used for the treatment of typhoid fever.

\begin{tabular}{|c|c|c|c|c|}
\hline Botanical Name & Common Name & Family Name & Part Used & Habit \\
\hline Psidium guajava Linn. & Guava & Myrtaceae & Leaf & Tree \\
\hline Terminalia catappa Linn. & Almond & Combretaceae & Leaf & Tree \\
\hline Citrus aurantifolia Swing. & Key lime & Rutaceae & Leaf & Tree \\
\hline Cymbopogon citratus (DC.) Stapf & Lemon grass & Poaceae & Leaf & Herb \\
\hline Azadirachta indica A. Juss & Neem tree & Meliaceae & Leaf & Tree \\
\hline Musa paradisiaca Linn. & Banana & Musaceae & Leaf & Shrub \\
\hline Citrus paradisi Linn. & Grape fruit & Rutaceae & Leaf & Tree \\
\hline Momordica charantia Linn. & Bitter lemon & Cucurbitaceae & Leaf & Climbers \\
\hline Ocimum gratissimum Linn. & African basil & Lamiaceae & Leaf & Herb \\
\hline Carica papaya Linn. & Pawpaw & Caricaceae & Leaf & Shrub \\
\hline
\end{tabular}

The profile of plants in this investigation revealed that the samples were from the families Euphorbiaceae, Laminaceae, Nictaginaceae, Asclepiadaceae, Caricaceae, Anacardiaceae, Rubiaceae, Maliaceae, Apocynaceae, Sapindaceae, Myrtaceae, Combretaceae, Rutaceae, Poaceae, Musaceae, Cucurbitaceae. The test plants were $90 \%$ trees, $50 \%$ shrubs, $40 \%$ herbs, $20 \%$ climbers having leaves as the only used plant part in the study (Table $1 \& 2$ ). Among the plants used for the treatment of arthritis and typhoid fever, Carica papaya appeared for both treatments. From the results of Table 3 , there seems to be an order, very high amount of alkaloids and flavonoids, moderate amount of saponins but little amount of tannins and carotenoids in the tested plant extracts. The qualitative

Table 3: Bioactive compounds in plants and their average amount used in the treatment of arthritis.

\begin{tabular}{|c|c|c|c|c|c|}
\hline Plant & $\begin{array}{c}\text { Tannins } \\
(\mathrm{mg} / 100 \mathrm{~g})\end{array}$ & $\begin{array}{c}\text { Saponins } \\
\text { (mg/100g) }\end{array}$ & $\begin{array}{c}\text { Alkaloids } \\
\text { (mg/100g) }\end{array}$ & $\begin{array}{l}\text { Flavonoids } \\
\text { (mg/100g) }\end{array}$ & $\begin{array}{l}\text { Carotenoids } \\
\text { (mg/100g) }\end{array}$ \\
\hline Spondias mombin & 45.5 & 650 & 2350 & 1550 & 137 \\
\hline Alstonia boonei & 94 & 1200 & 3340 & 2190 & 67 \\
\hline Blighia sapida & 58 & 950 & 965 & 860 & 34 \\
\hline Phyllantus amarus & 96 & 620 & 1870 & 1140 & 185 \\
\hline Solenostemon monostachyus & 76 & 865 & 3450 & 1150 & 95 \\
\hline Khaya grandifoliola & 64 & 560 & 680 & 1590 & 45 \\
\hline
\end{tabular}

analysis was derived from the quantitative analysis and rated according to the highest and lowest figures present in the column Table 4. As observed in Table 5, the amount of saponins, alkaloids and flavonoids in the tested plant extracts were high contrary to their very low amounts of tannins and carotenoids. These tested plants used in the treatment of typhoid fever seem to contain relatively high amounts of saponins, alkaloids and flavonoids. Table 6 represents the qualitative phyto-chemical analyses of some plant extracts used in the treatment of typhoid fever in the African-Nigerian locality. Saponin is absent in Citrus sinensis as the only absence recorded in all the samples tested.

(Research Support R \& D Analytical Services), Trans Amusement Park, Old Airport Road, Bodija, Ibadan, Nigeria using standard methods [5-7]. 
Journal of Complementary Medicine \& Alternative Healthcare

\begin{tabular}{|c|c|c|c|c|c|}
\hline Boerhavia diffusa & 72 & 760 & 1740 & 2140 & 171 \\
\hline Parquetina nigrescens & 53 & 90 & 890 & 1165 & 86 \\
\hline Morinda lucida & 166 & 350 & 3520 & 860 & 55 \\
\hline Carica papaya & 138 & 1075 & 2460 & 650 & 245 \\
\hline
\end{tabular}

Table 4: Qualitative phyto-chemical analysis of plants used in the treatment of arthritis.

\begin{tabular}{|c|c|c|c|c|c|}
\hline Plant & $\begin{array}{l}\text { Tannins } \\
(\mathrm{mg} / \mathbf{1 0 0 g})\end{array}$ & $\begin{array}{l}\text { Saponins } \\
(\mathrm{mg} / \mathbf{1 0 0 g})\end{array}$ & $\begin{array}{l}\text { Alkaloids } \\
\text { (mg/100g) }\end{array}$ & $\begin{array}{l}\text { Flavonoids } \\
\text { (mg/100g) }\end{array}$ & $\begin{array}{l}\text { Carotenoids } \\
\text { (mg/100g) }\end{array}$ \\
\hline Spondias mombin & + & ++ & +++ & ++++ & +++ \\
\hline Alstonia boonei & ++ & +++ & ++++ & ++++ & ++ \\
\hline Blighia sapida & ++ & ++ & ++ & ++ & + \\
\hline Phyllantus amarus & ++ & ++ & +++ & +++ & ++++ \\
\hline Solenostemon monostachyus & ++ & ++ & ++++ & +++ & ++ \\
\hline Khaya grandifoliolia & ++ & ++ & ++ & +++ & + \\
\hline Boerhavia diffusa & ++ & ++ & +++ & ++++ & ++++ \\
\hline Parquetina nigrescens & ++ & + & ++ & +++ & ++ \\
\hline Morinda lucida & ++++ & + & ++++ & ++ & ++ \\
\hline Carica papaya & +++ & +++ & +++ & ++ & ++++ \\
\hline
\end{tabular}

KEY: ++++Very High +++High ++Moderate +Low

Table 5: Phyto-chemical contents in plants used for the treatment of typhoid fever.

\begin{tabular}{|c|c|c|c|c|c|}
\hline Plant & $\begin{array}{c}\text { Tannins } \\
(\mathbf{m g} / \mathbf{1 0 0 g})\end{array}$ & $\begin{array}{c}\text { Saponins } \\
\mathbf{( m g / 1 0 0 g})\end{array}$ & $\begin{array}{c}\text { Alkaloids } \\
\text { (mg/100g) }\end{array}$ & $\begin{array}{c}\text { Flavonoids } \\
\text { (mg/100g) }\end{array}$ & $\begin{array}{c}\text { Carotenoids } \\
\mathbf{( m g} / \mathbf{1 0 0 g})\end{array}$ \\
\hline Musa paradisiaca & 22 & 1865 & 780 & 2355 & 150 \\
\hline Azadirachta indica & 165 & 1340 & 3600 & 1870 & 28 \\
\hline Momordica charantia & 142 & 2750 & 2950 & 1520 & 235 \\
\hline Citrus sinensis & 83 & 1350 & 760 & 980 & 74 \\
\hline Citrus aurantifolia & 90 & 750 & 1475 & 680 & 162 \\
\hline Citrus paradisi & 125 & 980 & 450 & 880 & 78 \\
\hline Terminalia catappa & 68 & 1945 & 2360 & 450 & 36 \\
\hline Ocimum gratissimum & 186 & 1350 & 2110 & 2115 & 196.5 \\
\hline Cymbopogon citrates & 175 & 345 & 1650 & 2255 & 232 \\
\hline Psidium guajava & 25 & 450 & 2150 & 1350 & 116 \\
\hline
\end{tabular}

Table 6: Qualitative analysis of plant extracts used in the treatment of typhoid fever.

\begin{tabular}{|c|c|c|c|c|c|}
\hline Plant & $\begin{array}{c}\text { Tannins } \\
(\mathrm{mg} / \mathbf{1 0 0 g})\end{array}$ & $\begin{array}{l}\text { Saponins } \\
\text { (mg/100g) }\end{array}$ & $\begin{array}{l}\text { Alkaloids } \\
\text { (mg/100g) }\end{array}$ & $\begin{array}{l}\text { Flavonoids } \\
\text { (mg/100g) }\end{array}$ & $\begin{array}{l}\text { Carotenoids } \\
\text { (mg/100g) }\end{array}$ \\
\hline Musa parasidiaca & + & ++++ & ++ & ++++ & +++ \\
\hline Azadirachta indica & ++++ & +++ & ++++ & ++++ & + \\
\hline Momordica charantia & +++ & ++++ & ++++ & ++++ & ++++ \\
\hline Citrus sinensis & ++ & - & ++ & ++ & ++ \\
\hline Citrus aurantifolia & ++ & ++ & ++ & ++ & +++ \\
\hline Citrus paradisi & +++ & ++ & + & ++ & ++ \\
\hline Terminalia catappa & ++ & ++++ & +++ & + & + \\
\hline Ocimum gratissimum & ++++ & +++ & +++ & ++++ & ++++ \\
\hline Cymbopogon citrates & ++++ & + & +++ & ++++ & ++++ \\
\hline Psidium guajava & + & + & +++ & +++ & +++ \\
\hline
\end{tabular}

KEY: ++++Very High +++High ++Moderate +Low

Discussion

Plant screened contained phytochemical compounds in varied concentration. Most of the tested samples contained high amounts of saponin, alkaloids and flavonoids but moderate amounts of tannins and carotenoids. Researches have shown that over $90 \%$ of most isolated chemical constituents of plants are alkaloids [8]. 
Alstonia boonei have been used topically to reduce swellings and in treating rheumatic fever, muscular pain and hypertension [9]. In other findings, the anti-inflammatory properties of the alcohol extract of Alstonia boonei have been applied in herbal treatment of muscular pain and rheumatic fever [10]. Carica papaya occurrence in the two-treatment list for arthritis and typhoid diseases is suggestive of its versatility. Ming et al. [11] stated that pawpaw is an exceptionally promising system for the exploration of tropical-tree genomes and fruit-tree genomics. He reported further in the draft genome sequence of 'SunUp' papaya, as the first commercial virus-resistant transgenic fruit tree to be sequenced. In this investigation, carotenoids seem low in Azadiractha in dica. This finding tally with those described by Evans and Trease [12] and by Unnikannan et al. [13] who studied the effects of chromium on certain tree species. These secondary metabolites observed in $A$. indica could be responsible for its antimicrobial activities on $S$. aureus, E. coli and S. typhi characterizing the specific active constituent responsible for its therapeutic value. Alkaloids are known for their anti-inflammatory effects. Flavonoids which are naturally occurring phenolic compounds with anti-oxidative properties have earlier been described in Carica papaya and Parquetina nigrescens [14].

Phytochemicals exert antimicrobial activities through different mechanisms. For instance, tannins act by iron deprivation, hydrogen binding or specific interactions with vital proteins such as enzymes found in microbial cells $[15,16]$. Tannins have also been reported to induce anti-plasmodial activities $[17,18]$. Akinjogunla et al. [19] reported the efficacy of extracts of Ocimum gratissimum on Escherichia coli. Terminalia catappa had been earlier been observed to contain high amount of saponins in comparison with all other secondary metabolites. Saponins are major natural anti-oxidants with anti-carcinogenic properties. They have reducing power capabilities and are recognized as inhibitors of peroxidation [20]. Conclusively, the phytochemical compounds found in these plant samples may play significant roles in the treatment of arthritis and typhoid fever evidenced from existing literature and findings on these compounds. Their extraction and purification should be of value to drug development and therapeutics.

\section{Acknowledgements}

Authors are grateful to the members of staff of the Laboratory Unit, Department of Chemical Pathology and Immunology, University College Hospital, Ibadan, Nigeria for technical assistance.

\section{References}

1. Farnsworth NR (1989) Screening Plants for New Medicines. National Academic Press, Washington, USA, pp. 83-97.

2. Trease GE, Evans WC (2002) A Textbook of Pharmacognosy. $4^{\text {th }}$ (edn.), SWB Saunders Co Ltd, London. Pp. 511.
3. Sofowora A (1993) Medicinal Plants and Traditional Medicine in Africa. Spectrum Books Ltd, Ibadan, pp.289.

4. Ojewole JAO (1984) Studies on pharmacology of echitamine, an alkaloid from the stem bark of Alstonia boonei L. (Apocynaceae). International Journal of Crude Drug Research 22: 121-143.

5. Harborne JB (1973) Phytochemical methods. Chapman and Hall Ltd. London. Pp. 49-188.

6. Trease GE, Evans WC (1989) Pharmacology $11^{\text {th }}$ (edn.), Bailliere Tindall Ltd., London. Pp. 60-75.

7. Obdoni BO, Ochuko PO (2001) Phytochemical studies and comparative efficacy of the crude extracts of some Homeostatic plants in Edo and Delta States of Nigeria. Global J Pure Appl Sci 8(2): 203-208.

8. Faparusi SI, Bassir O (1972) Triterpenes from Alstonia boonei. Phytochemistry 21: 3083-3084.

9. Sarpong LM (2011) Anti-plasmodial constituents in the leaves and stem barks of Carapa procera DC (Meliaceae). Kwame Nkrumah University of Science and Technology, Kumasi, Ghana, pp. 97.

10. Majekodunmi SO, Adegoke OA, Odeku OA (2008) Formulation of the extract of the stem bark of Alstonia boonei as tablet dosage form. Tropical Journal of Pharmaceutical Research 7(2): 987-994.

11. Ming R, Hou S, Feng Y, Yu Q Dionne Laporte, et al. (2008) The draft genome of the transgenic tropical fruit tree papaya (Carica papaya Linnaeus). Nature 452(7190): 991-996.

12. Evans WC, Trease GE (1989) Pharmacognosy. $13^{\text {th }}$ (edn.), Bailliere Tindall, London, pp. 832.

13. Unnikannan P, Baskaran L, Chidambaram ALA, Sundaramoorthy $P$ (2013) Chromium phytotoxicity in tree species and its role on phytoremediation. Insight Botany 3: 15-25.

14. Imaga NA, Gbenle GO, Okochi VI, Adenekan S, Duro Emmanuel T, et al. (2010) Phytochemical and antioxidant nutrient constituents of Carica papaya and Parquetina nigrescens extracts. Scientific Research and Essays 5(16): 2201-2205.

15. Akinpelu DA, Aiyegoro, Okoh OA (2008) In vitro antibacterial and phytochemical properties of crude extract of stem bark of Afzelia africana (Smith). African Journal of Biotechnology 7(20): 3662-3667.

16. Adejuwon AO, Bisi Johnson MA, Obuotor TM, Agboola OA (2011) Bioactive compounds and antimicrobial efficacy of the extracts of Combretum pincianum Hook. Journal of Medicinal Plants Research 5(15): 3561-3563.

17. Dharmananda S (2003) Gallnuts and the Uses of Tannins in Chinese Medicine. In: Proceedings of the Institute for Traditional Medicine, Portland, Oregon, USA.

18. Faparusi F, Bello Akinosho MM, Oyede RT, Adewole A, Bankole P, et al. (2012) Phytochemical screening and antimicrobial activity of Brillantaisia patella leaf. Research Journal of Phytochemistry 6(1): 9-16.

19. Akinjogunla OJ, Ekoi OH, Odeyemi AT (2011) Phytochemical screening and in-vitro antibacterial assessment of aqueous leaf extracts of Vernonia amygdalina (Asteraceae) and Ocimum gratissimum (Lamiaceae) on moxifloxacin resistant Escherichia coli isolated from clinical and environmental samples. Nature and Science 9(7): 42-52.

20. Odugbemi T (2008) A Textbook of Medicinal Plants from Nigeria. Tolu Odugbemi Publishers Nigeria. Pp. 628. 


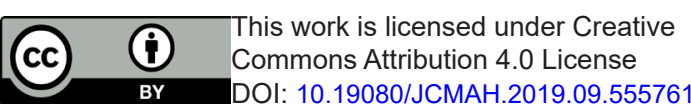

BY DOI: 10.19080/JCMAH.2019.09.555761

\section{Your next submission with Juniper Publishers will reach you the below assets}

- Quality Editorial service

- Swift Peer Review

- Reprints availability

- E-prints Service

- Manuscript Podcast for convenient understanding

- Global attainment for your research

- Manuscript accessibility in different formats ( Pdf, E-pub, Full Text, Audio)

- Unceasing customer service

Track the below URL for one-step submission https://juniperpublishers.com/online-submission.php 